\title{
Bringing the crucified down from the cross Preferential option for the poor in the South African context of poverty
}

\section{Olehile Buffel ${ }^{1}$}

\section{Abstract}

This article makes an argument for the need and relevance of liberation theology and particularly its preferential option for the poor in the context of poverty. Post colonial and post-apartheid Southern African (and most if not all African) countries are still impoverished, with millions of the their citizens still living in dehumanising poverty despite the political liberation in the hands of the African rulers who replaced colonial and apartheid masters. Despite liberation and the dawn of democratic governments in Southern Africa millions of people are still suffering as a result of poverty. While the former colonies have been bequeathed some negative legacies that refuse to disappear, the main concern is that African leaders have failed to use the political powers at their disposal to bring about economic liberation and to transform the socio-economic and political structures that are responsible for the continuation of poverty. In the midst of these conditions that ensure the perpetuation of poverty and associated suffering theologians and pastors are disturbingly quiet and also failing to facilitate theological reflections in the context of poverty, to the extent that one is forced to ask some hard questions: On whose side are the pastors and theologians? On whose side is God? If as liberation theologians correctly argue that God is on the side of the poor, can theologians afford to be on a different side? Can they afford to be on a different side as they do theology, particularly as they do theology of missions? They are challenged to appropriate Jon Sobrino's theology of the "crucified peoples" and therefore make efforts to contribute to "bringing the crucified down from the cross" as they minister and as they reflect theologically.

Key words: Preferential option, poverty, liberation theology, crucified peoples, suffering, oppression, socio-economic structures, humanisation

\section{Introduction}

This article grapples with the phrase "preferential option of the poor" that became common amongst liberation theologians, initially in Latin America, the U.S.A (Black Theology) and later in other parts of the developing world such as Africa where poverty was (and is still) widespread. Liberation theologians

1 Dr. Olehile Buffel teaches Practical Theology in the Department of Philosophy, Practical theology and Systematic theology at the University of South Africa. He can be contacted at Buffeoa@unisa.ac.za 
uphold an unapologetic consensus with regard to this controversial phrase, 'preferential option for the poor' (Buffel 2010:100). This phrase has been controversial from the very beginning of liberation theology in Latin America and later in other parts of the world such as the U.S.A and South Africa. The article argues that this controversial phrase should still be a major issue in Africa, and particularly in South Africa given the untold suffering and dehumanisation of millions as a result of the widespread poverty. This is despite the fact that South Africa is now a politically liberated country, which is democratic country which has one of the best and most acclaimed constitutions in the world since 1994. Since then South Africa has held a number of "generally free and fair elections which have been conducted since 1994" (Jeffrey 2010:1). Poverty is arguably one of the biggest problems confronting South Africa after 21 years of political freedom which has not yet been translated into economic liberation for the poor. Like other former colonies that have gained independence from their colonial masters, the political leadership of South Africa have failed dismally to use the political power at their disposal to bring about economic liberation and to transform the socio-economic and political structures in which poverty is entrenched. A striking feature of the South African situation is that the churches, pastors and theologians who played a significant role during the struggle for liberation are now disturbingly quiet and apathetic in the midst of pain, suffering, marginalisation and dehumanisation as a result of poverty. This begs the question that has been posed by MacMaster (2008): "Where have all the pastors gone?" One could extend it to: Where have all the prophets and theologians gone? Where have the ecumenical structures (such as the South African Council of Churches) that championed the struggle for political liberation gone? In line with the "preferential option for the poor" the church, pastors and theologians are challenged to wake up from their slumber and to be on the side of the poor. If as liberation theologians correctly claim that God is on the side of the poor, can the church, pastors and theologians afford to be on the wrong side? Can their theological discourses afford not to be on the side of the poor? In this article they are challenged to make a contribution to bring down the crucified people (poor) down from the cross by journeying alongside the poor and participating with the poor in the struggle for economic liberation. This can be done according to Saayman (2007:5) by being missionary and human. As Saayman (2007:5) correctly points out that the invitation of Jesus of Nazareth to his disciples is actually the invitation to participate in his liberating, healing and evangelising mission (John 20, Luke 4). This is an invitation to be "missionary while being human", to use a phrase from Saayman (2007). Therefore doing theology must be a humanising and liberating process. In 
particular doing theology of Christian mission must also be a humanising and liberating enterprise.

\section{The origins of this controversial phrase}

This controversial phrase 'preferential option for the poor' was first coined and popularised at Puebla within the Latin American church (cf. Bosch 2008: 435; Reiser 1995:3, 4). As Maimela (1990:172) correctly points out, the phrase, together with liberation theology of which the phrase is an important component, has its roots in the history of the church (and the history of its theology) and its society. The Christian church has often been influenced by the changing nature of society in which it finds itself (Maimela 1990: 172). According to Reiser (1995:4) this phrase featured prominently in the deliberations of the Latin American bishops who were assembled in the Mexican city of Puebla in 1979, although the foundations thereof went back to their earlier meeting in Medellin, Colombia eleven years earlier in 1968. The Latin American Bishops conference (CELAM) can be considered the "official launching" of the theme of liberation, with this controversial phrase, "preferential option for the poor' (Boff and Boff 1987: 9: cf. Vila-Vicencio 1990:153). Since that time this has become the most controversial religious term since the Reformers' cry, "Salvation by faith alone" (Dorr 1992:1; cf. Moodie 2006:46). Moodie (2006:46) correctly points out that in some ways the phrase "God's preferential option of the poor" might be seen to be a deliberately controversial and provocative statement to shake us out of our places of comfort and self-satisfaction in a world of exploitation and extreme poverty. Writing in the South African context, Nolan (1985:188) also acknowledged the controversial nature of this phrase particularly in his statement that this phrase challenges churches and theologians in a very fundamental way (cf. Gutierrez 2005:19). According to Nolan (1987:1) it is not only this phrase that is controversial, but the whole theology of liberation which during the struggle for liberation was a controversial subject in South Africa and elsewhere in the world. He was writing in the context of apartheid South Africa during the time of repression and the State of emergency that was declared on June 1986. In the South African context it was not only a controversial phrase but also a dangerous and risky business according to Boesak (1976: xi) who wrote: "Engaging in liberation theology in the South African situation is an extremely difficult and risky business." It is now common knowledge that pastors, theologians and other activists suffered all sorts of harassment and torture, including detention without trial and physical poisoning and petrol bombings of their houses for their articulation and support of liberation theology in the hands of the apartheid regime and its security forces. Now that official apartheid is gone from the statutes and all citizens are able to cast their votes and even be in both parliament and in government, can 
we say that liberation theology is no longer controversial, risky and necessary? The fact of the matter is that there are still millions of people, predominantly black, to whom the fruits of a liberated and democratic South Africa are elusive. Hence the need of this preferential option of the poor and oppressed (Buffel 2010: 100). South Africa may no longer have a political crisis marked by repression and states of emergency, but we still have an economic crisis in South Africa. Perhaps not from the perspectives of the rich and the few elites but that is the case from the perspective of millions who are still poor in the South Africa context. There is therefore still the need for a conversion to boldness (parrhesia) and a theology that is against all forms of suffering, oppression and injustices both in South Africa and in the world. In the words of the bishops at Puebla as cited by Gutierrez (1990:1) theology must be done in such a way that it seeks "ways of announcing the gospel for the time to come". Theology must be done in such a way that it is liberating and humanising. Thus the church, as a whole and in particular the leaders and theologians are still called to conversion. As Gutierrez (1990:8) correctly states, 'there is no other way to preach the gospel'.

When this term burst on to the ecclesiastical scene the leaders of the church were committed to efforts to implement the renewal that was sparked off by the Vatican II (1968-1965) (cf. Dorr 1992:1). This Council became a watershed event in the Roman Catholic Church which changed Catholic theology in very significant ways (cf. Pratt 1995:13). The impact of the Vatican Council did not only end within the boundaries of the Catholic Church but influenced the Protestant churches and the broader ecumenical movement in significant ways. Since that Council notions such as 'theology of liberation' and 'God's preferential option for the poor' have become common parlance in religious discourse in the Catholic Church, Protestant churches and in the ecumenical circles. When this happened, according to one of the pioneers of liberation theology, Gustavo Gutierrez the leaders were involved in "ways of announcing the gospel for the time to come . . there is no other way to preach the gospel" (Gutierrez 1990:1, 8). At Puebla, where this phrase was first coined, the assembly of the bishops was calling "all Christians and the church as a whole to conversion" (Gutierrez 1990:8). This was a call to what the church of the Acts of the Apostles called parrhesia, that is, boldness, outspokenness. This is the opposite of the timidity that is often present in churches and among theologians and pastors. According to Gutierrez (1990:8) this was a call to "confront the present challenges with parrhesia (boldness)". These are the challenges that are still prevalent in slightly different forms and contexts that still require the boldness and outspokenness of the church and of theologians of today. It was thus at Puebla where liberation theology, with its preferential option for the poor was endorsed and an even deeper interest in it was aroused (cf. Boff and Boff 1984). 
When this phrase arrived on the scene at Puebla the bishops wrote:

with regard to renewed hope in the vivifying power of the spirit, we are going to take up once again the position of the Second General Conference of the Latin American episcopate in Medellin, which adopted a clear and prophetic option expressing preference for and solidarity with the poor ... we affirm the need for conversion on the part of the whole church to a preferential option for the poor, an option aimed at their integral liberation (Reiser 1995:4).

According to Reiser (1995:5) the option for the poor is about a communion or a solidarity which is for the poor, with the poor, and against all forms of human poverty (and oppression). This was not merely a pious rhetoric, but a phrase that was critical and central to liberation theology. From the beginning the phrase had become a central axis of liberation theology (cf. Bosch 2008: 77). The option for the poor is about the refusal of the church, its pastors and theologians to be part of the dehumanising structures that cause and perpetuate poverty.

\section{The meaning of the phrase according to liberation theologians}

Liberation theologians insist correctly that this phrase means that God is on the side of the poor and oppressed. God is not aloof and neutral. To emphasise this point one of the leading liberation theologians in South Africa, Maimela (1998:118) states that: "God is a thoroughly biased God who was (and is still) always taking the side of the oppressed, of the weak, and of the exploited, homeless and of the scum of society." Maimela (1993:59) argues that God is the God who expresses his divine concern for the underdogs. They are the marginalised people who are pushed to the underside of history (Rieger 1998:1; cf. Bosch 2008: 438). This preferential option for the poor, the marginalised and the oppressed is not only based on the compassionate feelings (feelings of pity such as 'Ag shame') for the underdog but on a biblical foundation. Maimela (1986:106) goes on to articulate it as follows in the context of Black Theology:

According to Black Theology, God has already taken sides with the oppressed, the outcasts and despised, when God elected to liberate Israel from Egyptian bondage. It is preferential option for the poor which was brought to a new height in the coming of Jesus, who was himself a poor and oppressed man of sorrows, who suffered and was crucified as the criminal and the rejected outcast. In the light of this revealed preferential option thrust, black theologians, struggling for justice, believe that Christians and churches must also take the side of the poor, to claim solidarity with them in their struggle, thereby liberating the oppressed from misery and marginality, and bringing down the powerful from their thrones (cf. Martey 1993:97) 
The poor and the oppressed are granted a hermeneutical privilege, which is the result of a rereading of the Bible (Martey 1993:97). The fact that the poor have a special place in God's plans in history is not something that is as recent as the 1960's when liberation theologians coined the phrase. Rather it is an insight that is as old as the events and stories captured in the Bible. According to Neuhaus (1988: vii): "the idea that the poor have a special place in God's purposes is hardly an insight produced by the last ten or twenty years (or even thirty years), nor does one have to leap back over centuries to discover the insight in Bible politics." The God of the Bible has always been consistent in terms of siding with the weak, the widows, the poor and the oppressed and the righteous. Those who ignore the plight of the poor can hardly be considered to be righteous, however pious, let alone those who are responsible for the perpetuation of poverty in any society. According to Bosch (2008:436) there can be no doubt that in both the Old and New Testaments (history of Israel and the ministry of Jesus Christ) there was a significant focus on the poor and their plight. The entire Bible beginning with the story of Cain and Abel mirrors God's predilection for the weak and abused in history. Bosch goes on to point out correctly that much of the pro-poor, pro-marginalised ethos was preserved during the first centuries of the Christian church. After Constantine, when the church became co-opted by the ruling class and the powers that be, and the church got richer and more privileged, the poor were increasingly neglected or treated condescendingly (Bosch 2008: 436: cf. Gutierrez 1988: xvii). They were treated in a dehumanising way. When this co-option by the ruling class took place, its interests, hopes, struggles and ambitions were aligned with those of particular sections of the Western society. At that stage Christianity had become a religion of the ruling class, which happened to be European, white and rich, as well as economically, politically and culturally privileged, rich and powerful. In the process it became alienated from common people, who were oppressed by rich and mighty (cf. Maimela 1990:172). That is when the church started to loose its plot, when its theology and its missionary endeavours tended to legitimise the social, cultural, political and economic interests of powerful few at the expense of the oppressed majority (cf. Maimela 1990:172). Liberation theology and its phrase therefore make a (still) necessary and radical break with the past.

Brown (1978) refers extensively to the Exodus story (Exodus 1:8-14; Ex 2: 2335; Ex 3:7-10) to illustrate the point that God has always sided with the oppressed as God did with the Israelites when they were oppressed in Egypt. God intervened to free the poor and the oppressed. The Israelites were oppressed and the Egyptians were the oppressors. Things were not only tough but they were continually getting tougher, as it is the case in the world and in South Africa where things are getting tougher, as the poor become poorer and the richer become richer. This had hap- 
pened in Brazil and it is happening in South Africa. When Brazil seemed to be making remarkable progress with its economy Boff (1987:5) had this to say:

The last twenty years have seen undeniable technological and industrial progress, but at the same time there had been a considerable worsening of social conditions, with exploitation, destitution, and hunger on a scale previously unknown in Brazilian history. This has been the price paid by the poor for this type of elitist, exploitative, and exclusivist development in which, in the words of Pope John II, the rich become richer at the expense of the poor who become poorer

Although this statement was penned down over twenty years ago (during the 1980's) it still holds true for many developing countries, and in particular for South Africa which has gone on to overtake Brazil as the worst in terms of the inequality gap between the rich and the poor. In support of the ever worsening plight of the poor, Sobrino (1991:120) had this to say: "terrible poverty is increasing all the time". He may have been writing a while ago in the Latin American context, but these are sentiments that the poor and those who work with and alongside the poor can identify with. The truth of the matter is that poverty, which Sobrino referred to as a colossal disaster, is increasing in the whole world particularly in the developing world (cf. Sobrino 1991:121). This according to Sobrino is so terrible and devastating that he refers to the poor as the "crucified peoples" (cf. Sobrino 1991:121). Sobrino (1991:121) states:

The crucified people is a useful and necessary language at the level of fact because the cross means death and death is what Latin American people are subjected to in a thousand ways

This terrible and devastating poverty is also dehumanising the poor, that is, the crucified peoples of the world.

Millions of people today are still 'crucified', that is, they are subjected to death a thousand times. This is true in the case of South Africa. Gutierrez (1999:23) reminds us that "poverty has increased dramatically . . . and the gap between the rich and the poor nations is today wider than two decades ago".

Gutierrez (1983:7) is correct and he is also in agreement with other liberation theologians that the God of the Bible is the God who takes sides with the poor and liberates them from slavery and oppression (cf. Brown 1978: Bosch 2008). Oppression and impoverishment are not consistent with the gospel (cf. Young 1990:1). In fact poverty is not only inconsistent with the gospel it is also scandalous (cf. Miguez Bonino 1975: 112). Gutierrez (1983: 28) argues that poverty is an injustice and the exploitation of human beings by other human beings to form a situation that the Medellin conference did not hesitate to condemn as 'institution- 
alised violence' which is as bad as death, premature death (Gutierrez 1996:26: cf. Rawland 1999:2; Sobrino 1991:121). They are subjected to slow but certain death caused by poverty generated by unjust structures. They die before their time as a result of this (Sobrino 1991:121). According to Miguez Bonino it is "a scandalous fact which must be eliminated. God himself ( ic $)$ is engaged in the struggle against it and he (sic) is clearly and unequivocally on the side of the poor" (1975:112).

In this 'preferential option for the poor' the church and its leadership and theologians are challenged to also be on the side of the poor. Bosch (1998: 436) insisted that the church has no choice but to demonstrate solidarity with the poor. Reiser (1995:5) is in agreement with Bosch when he states that this option for the poor is about a communion or solidarity which is "for the poor, with the poor, and against all forms of human poverty."

\section{A critique of the critics of liberation theology and the preferential option for the poor}

Liberation theology and its controversial phrase 'preferential option' for the poor are not without critics or those who are hostile towards liberation theology. Liberation theology makes some people in church and academic circles very uncomfortable. As expected there are conservatives, some liberal theologians and counter-revolutionaries and reactionaries who dismiss liberation theology and all that is associated with it. They dismiss that as non-theological (non-academic) and unscientific, as if they have the monopoly on what is in compliance with standards and ways of thinking about theology. Furthermore they dismiss it as a passing fad that has no place or space on the table of academic and theological discourse. Many of these objectors and critics do not care about the lot of the poor and the oppressed. They do not care about the scandalous dehumanising experience to which the poor are subjected. According to Dorr (1992) they see liberation theology as politicisation of faith. These are the people who are not opposed to helping the poor. Rather they see liberation theology as a dangerous threat to the stability of society and to the teaching authority of church leaders. All they want to prescribe for the poor is superficial charity and an "ambulance ministry" that maintains the status quo. Many well meaning Christians throughout the world have consensus that social ills have to be remedied but without challenging societal and political micro and macro structures of societies (cf. Bosch 1991:433). The critics go on to dismiss liberation theology as Marxist-influenced, as communism in a religious garb, as undue mixing of religion with politics and not compliant with theological standards normally associated with Western theology that claims to be universal, implicitly and explicitly (cf. Buffel 2010). According to Vila-Vicencio (1990: 155) critics often reduce liberation theology to a little more than a Christian facade behind which a Marxist agenda is found. Such attacks ignore the insistence 
of Gustavo Gutierrez's statement in his formative study that: "liberation theology is a critical reflection on Christian praxis in the light of the word." (Gutierrez 1988:xxiv: cf. Vila-Vicencio 1990: 155; Bosch 1991).

Maimela (1993: 59) notes without any surprise that liberation theology and its preferential option for the poor will always be met with hostility by its selfappointed critics. He said:

As to be expected, the assertion that the Church should take a preferential option for the poor and be the advocate and defender of the oppressed has invoked great hostility from both the conservative and liberal theologians, who interpret it to mean that God is now portrayed as against the rich and the white Christians (Maimela 1993:59).

There is no doubt that the biblical God has always been on the side of the weak, the orphans, the poor and the oppressed. Liberation theologians insist therefore that this preferential option for the poor is both biblical and theological. It is certainly not any less theological than the theologies of the West. If God is on the side of the poor how can the church and its theologians be on a different side? Thus the poor are granted an epistemological privilege. Bosch (1991: 436), an Afrikaner (and leading missiologist) who was way ahead of his time maintains that the poor are entitled to what is referred to as an "epistemological privilege". It means that the liberation of the poor is epistemologically central (cf. Nicholson 1990:164). Segundo (1993:125) also emphasised epistemological privilege, in which there is preference for the poor. He goes on to say: "I do not believe that there is any other way of expressing the option for the poor concretely than to say it is God's compassion for the most afflicted." The church, its theologians and our theological discourse should also be on the side of the poor and the oppressed. In agreement with the biblical and theological foundations of this preferential option for the poor Domeris (1986:57) points out that "God's concern for the poor is a recurrent theme in both the Old and New testaments." He also tries to locate the argument within the South African context by saying:

Given the central place allocated to this theme in liberation theology, it is not surprising to find that the category of the poor and their place within the salvation planned by God has become a major issue for South African churches (Domeris 1986:57).

This preferential option for the poor should still be a major issue in South Africa today given the extent of suffering and dehumanisation as a result of poverty.

\section{Poverty in the South African context}

Poverty is rife and widespread in South Africa. It also is very unique in the sense that it is in contrast to other countries where poverty knows no colour. In South Africa it is mainly concentrated amongst blacks, without necessarily denying that there are 
whites who are poor. The South African situation is exacerbated by racist legislation of the past, hence the South African poverty has very strong racial dimensions (cf. Mbuli 2008:5).The apartheid regime has inevitably bequeathed its racist legacy to the new South Africa. When the regime transferred political power following the elections of 1994, the economic power remained in the hands of the minority in the South African context. In this context the economic power is in the hands of a minority whereas the political power is in the hands of the (majority) blacks. What Wilson and Ramphele (1989:4) said some decades ago is still valid in South Africa, that is, that the degree of inequality is greater than any other country. According to Mbuli (2008:1) it is estimated that between $45-57 \%$ of South African are engulfed by poverty.

In terms of the Gini co-efficient, South Africa has the highest measure of inequality amongst 57 countries for which data is available (Wilson and Ramphele 1989:4). This is also supported by Mbuli (2008:1) who cites the World Bank which estimated the Gini co-efficient to be between 0.58 and 0.72 (cf. Saayman 2008:30). In South Africa poverty is characterised by the following:

- The width of the gulf between the rich and the poor i.e. the degree of inequality

- Poverty existing as a result of a deliberate policy

- Material poverty in South Africa was reinforced by racist laws that were an assault on people's humanity. Whereas most pieces of racist legislation have been removed from the statutes, the legacy of those racist policies still remains.

There is consensus amongst researchers that South Africa is an upper middle class country with per capita income similar to other countries such as Botswana, Brazil, Malaysia and Mauritius (Whiteford and Mcgrath 1994:1; cf. May 1998:1; Barberton et al 1998:13). Expressing the same point May (1998:1) says:

In per capita income terms South Africa is an upper middle class income country but most African households experience outright poverty or vulnerability to becoming poor. In addition the distribution of income and wealth in South Africa is the most unequal in the world.

Whereas South Africa is a middle class income country, i.e. a land of plenty, the majority of blacks (black Africans, Indians and coloureds) they are excluded from enjoying this relative wealth of the country. Writing in a global context and lamenting the conditions of poverty in that context, Smith (2005:5) expresses some optimism, when he says: "The good news is that the world produces enough food for all (Smith 2005:5).

This is a contradiction of our society. Poverty is prevalent in the midst of plenty. The author agrees with Dickinson (1983:3) who correctly pointed out to these contradictions when he said: "we live in the midst of paradoxes" 
Despite being the wealthiest country in Africa and being a middle class income country, South Africa displays human development more often associated with low-income countries (Whiteford 1995:1). In relative terms South Africa is not necessarily a poor country. Whereas the reality of "a not so poor country" may be a reality to the rich whites in South Africa, to the majority of black South African citizens, it is far from the truth. It is for that reason that researchers are agreed that South Africa has the most unequal distribution of income and wealth (May 1998:1; Whiteford and Mcgrath 1994:1; Wilson and Ramphele 1989:4; Bruggemans 2003:16).

The South African situation is marked by what some researchers call "extreme income inequality" (Barberton et al 1998:13). Furthermore the South African situation is marked by destitution, hunger, homelessness and overcrowding, illiteracy, HIV and Aids pandemic and other ills associated with poverty such as crime and violence. All these co-exist side by side with affluence. This is the context in which we have to develop and practice pastoral work, as well as do theology, both as practitioners and as theologians.

It is estimated that more than half of the households in South Africa are living in poverty i.e. below the minimum living level (MLL). According to researchers more than $50 \%$ of the South African population are rated as poor and they live on less than R12-00 per day (Pieterse 2001: ix; cf. May 2000:32). The reality is that blacks do not enjoy the fruits of the natural and other resources of the country in the same way that whites do, except of course for those few politically connected elites who have benefited from the Black Economic Empowerment (BEE).

In relative terms South Africa is a wealthy country. In fact by the standards of the developing world South Africa is one of the wealthiest countries on the African continent. Emphasising the same point, Roux (1999:146) correctly points out that: "Although South Africa makes up less than $0.5 \%$ of the world economy, on the African continent South Africa is a giant." Roux correctly points out that South Africa is by far the largest economy in Africa, with $28 \%$ of Gross National Product (GNP), produced in South Africa (Roux 1999:146). In the Sub-Saharan region South Africa is unequalled as the most developed country. Sunter (1987) concurs with Roux that South Africa is a relatively successful and the most sophisticated country in Africa. He particularly cites its excellent infrastructural development such as roads, bridges, electricity grid etc. In terms of developments South Africa is second to none in comparison to the rest of Africa. Sunter (1987:86) points out that: "The unfortunate thing is that all areas of the country do not enjoy the same quality of infrastructure." Those who have odds stacked against them in terms of infrastructural developments are blacks, whose areas are still subjected to underdevelopment and neglect. 


\section{The meaning of the option for the poor in the South African context}

The practical implication of this preferential option for the poor is that, through its conscientisation efforts it must seek to arouse and mobilise the poor and oppressed to take a clear option against poverty, oppression, suffering and dehumanisation and join the God of the Exodus and of Jesus the Christ (the liberator) to become instruments of their own liberation (cf. Martey 1993:98). According to Nolan (1985:192) an interesting thing about the Exodus story it is that the poor and oppressed on their part must take up an option for their own cause. He clarifies the point as follows:

The option for the poor is almost thought of as a commitment which the non-poor have to make to the cause of those who are oppressed. But what is far more fundamental in the Bible is the option of the poor for their own cause (Nolan 1985: 192).

Boff and Pixley (1989:xi) once wrote: "People are divided by the stand they take on poverty." The words tempt one to apply this to pastors, theologians and their theological discourses, which can also be divided by the stand they take on poverty. In the South African context theologians must do theology in the accompaniment of the poor, alongside and together with the poor. In our theological work and our ministry we have no option but to side with the poor of the world. It is generally agreed that God is on the side of the poor. I subscribes to that view. Our theology and our reflections must also adopt the preferential option of the poor, which is in fact biblical.

Therefore the church and its theology must also concretely express this option for the poor. If God is unequivocally on the side of the poor, can the church afford to be on a different side? Can pastoral workers afford to be on a different side? Can our theological discourse afford to ignore the realities experienced by the poor? Can the church afford to ignore the agency of the poor? The answer is an unequivocal No! Thus theological reflection and pastoral actions cannot afford to proceed unchallenged with their usual apathy towards the socio-economic and political conditions and the plight of the poor (Buffel 2010).

\section{The task of liberation theology}

The primary task of liberation theology as either part of or an ally (or an example) of political theology should be as follows:

- To de-privatise theology. This in my opinion also involves a move away from the tendency to over-spiritualise theology (Gutierrez 1983)

- To invite a critique of the very foundations of our contemporary theology. One could add here a point made by Pratt (1995) that liberation theology should 
critique and call into question the theological view which suggests that one should not worry about the suffering and misery of this world because if one lives a faithful life, God will reward us in the next life or in heaven. This is a sort of a "pie in the sky" theology which has no place in any contemporary society.

- To critique societies and the ideologies sustaining the different societies (see Berryman 1987:6).

- To critique the activity of the church, pastors, theologians and Christians in general from the perspective of the poor (cf. Berryman 1987:6). This is what liberation is all about, that is, to read and interpret the Bible, Christian doctrines from the perspectives of the poor. The need to give due respect and space to the agency of the poor in the struggle for liberation and in the process of doing theology cannot be over-emphasised. The elites can no longer pretend to be the voice of the voiceless, but space must be created for the voiceless to make their own voices heard (cf. Bosch 1991:436). This touches the important issue of a new and different methodology that combines theology and experience, that is, a new and different way of doing theology from the perspective of the poor and the marginalised (cf. Rawland 1999:2; West 1999).

- To rediscover the prophetic tradition and voice that is present in the Bible. This includes rediscovery of the boldness (outspokenness) of the early church which was lost at the time of the co-option of the church by ruling class from the time of Constantine, throughout the ages. This calls for organisational conversion on the part of the church as it becomes imperative for the church and its leadership to move away from timidity to boldness (outspokenness).

The challenge of theology and liberation theology in particular is according Sobrino, to contribute to "bringing the crucified people down from the cross" (1991:125). Sobrino whose theology of the crucified is useful here, points out: "

"We must bring the crucified peoples down from the cross. This is the requirement of an anthropology by which human beings can be justified ... this is the marrow of liberation theology"

However this contribution should be done in such a way that the crucified people themselves are the bearers of salvation. The agency of the crucified peoples is very critical. The church, theologians and pastors, including Christian and development workers are to accompany and journey with the crucified peoples (the poor) as they struggle for their own liberation, as they struggle to transform the socio-economic and political structures that are a cause of their poverty, oppression, suffering and dehumanisation. According to Berryman (1987:5) people do not simply happen to be poor but their poverty is a product of the way society is 
organised and structured. Poverty is not just the result of ignorance, lack of skills, moral or cultural factors, or laziness, but it has to do with cultural factors (cf. Bosch 1991:434). This in line with what Brown (1978:90) pointed out that "God who liberates not only from sin and guilt but also from the structures of the world that are evil, exploitative and unjust."

\section{Conclusion}

Although South Africa has made some progress in other areas since the political liberation of 1994, there are still millions of South Africans who are daily dehumanised by the prevalent poverty in the country. South Africa shares poverty and its associated ills with many other countries that have since been liberated from colonial masters, where the political leaders have failed to use the political power at their disposal to bring an end to the socio-economic and political structures that continue to perpetuate poverty in Africa. The situation in South Africa and elsewhere in Africa necessitates the "preferential option of the poor" which has been advocated by the liberation theologians. In this "preferential option for the poor" the church, pastors, theologians and Christians in general are challenged to refrain from being neutral and to be on the side of the crucified peoples (poor) of God. They are challenged to contribute to bringing down the crucified people from the cross. They are challenged to do what is advocated by Saayman when he says that Christian mission which has to be "humanising $(2007: 5,138)$." In this contribution they must take into account the agency of the poor and to walk alongside the poor mainly as facilitators in the struggle for economic liberation and the struggle for transformation of society. They are furthermore challenged to rediscover the prophetic tradition of the bible and confront with boldness the modern day Pharaohs (oppressors), that is, the socio-economic and political structures and the ideologies that are sustaining poverty. The church, pastors and theologians can no longer afford not to be on the side of the poor and to theologise from ivory towers of academic institutions and pretend to be aloof from the harsh realities affecting millions of the poor people in South Africa. They are challenged in the words of Jon Sobrino to make a contribution "to bring down the crucified peoples of God from the cross", and to do this alongside and together with the poor themselves. This must be done in a missionary way, which is a humanising way (cf. Saayman 2007).

\section{References}

Berryman, P. 1987. Liberation Theology: The Essential facts about the Revolutionary Movement in Latin America and beyond. New York. Pantheon Books.

Boesak, A. 1976. Farewell to Innocence: A socio-ethical Study on Black Theology and Power. Maryknoll, N.Y. Orbis Books 
Boff, L, and Boff C. 1984. Salvation and Liberation: In search of a Balance between Faith and Politics. Maryknoll, N.Y. Orbis Books.

Boff, L and Boff, C. 1989. Introducing Liberation Theology. Maryknoll, N.Y. Burns and Oates.

Boff L, and Elizondo, B. 1991. Editorial, The voices of the victims. Who will listen to them? SCM Press., pp. vii-X.

Boff, L and Pixley, G. 1989. The Bible, the Church and the Poor. Maryknol, N.Y. Orbis Books. Bosch, D. 1991.Transforming Mission: Paradigm Shifts in Theology of Mission. Maryknoll, N.Y. Orbis Books.

Bosch, D. 2008. Transforming Mission: Paradigm Shifts in Theology of Mission. Maryknoll, N.Y: Orbis Books.

Brown, R.M. 1978. Theology in a new key: Responding to liberation themes. Philadelphia. The Westminster Press

Bruggemans, C. 2003. Change of Pace: South Africa's economic revival. Johannesburg.

Wits University Press.

Buffel, O. A. 2010. Preferential option for the poor in the current context of poverty in South Africa: Doing Theology in the footsteps of Simon Maimela, in Studia Historiae Ecclesiasticae, June/ July 2010. Vol XXXVI, Supplement, pp. 99-113.

Domeris, B. 1986. Biblical perspectives on the poor, in Journal of Theology in South Arica, vol 57: 57-61

Dorr, D. 1992. Option for the Poor: A bundred years of Vatican Social Teaching. Maryknoll, N.Y. Orbis Books.

Gutierrez, G. 1983. The Power of the Poor in History. London. SCM Press

Gutierrez, G. 1988. A Theology of Liberation. Maryknoll, N.Y. Orbis books.

Gutierrez, G. 1990. Towards the Fifth Centenary, in The Voices of the Victims by Boff, L and Elizondo, V (eds), London. SCM Press, pp 1-9

Gutierrez, G. 1999. The task and content of Liberation Theology, in The Cambridge

companion of liberation theology, by Rawland C. (ed), Cambridge, Cambridge University Press. pp 19-38

Jeffrey, A. 2010. Chasing the Rainbow Nation: South Africa's Move from Mandela to Zuma. Johannesburg. South African Institute of Race Relations

MacMaster, L.M. 2008. Where have all the Pastors gone? A case for Public Pastoral Care in

a Democratic South Africa Experiencing Growing Pains, in Journal of Theology in South Africa, Vol 132 (November,2008), p 3-15

Maimela, S.S. 1990. Modern trends in Theology. Braamfontein. Skotaville.

Martey, E. 1993. African Theology: Inculturation and Liberation. Maryknoll. N.Y. Orbis books. Mbuli 2008. Poverty reduction strategies in South Africa. M.Com thesis. Unisa. Pretoria.

Miguez Bonino, J. 1975. Doing Theology in a Revolutionary situation. Philadelphia. Fortress Press.

May, J. Poverty and Inequality in South Africa: Report prepared for the office of the Deputy

President and inter-ministerial committee on Poverty and Inequality. Durban. Praxis. Moodie. B. D. 2006. A Provisional and symbolic re-reading ofJohn II in the light of the 
church's mission in solidarity with the poor: A reaffirmation of the preferential option of the poor. Unpublished M.Th dissertation. Pretoria: Unisa.

Neuhaus, R.J. (ed) 1988. The preferential option for the Poor. Michigan, Grand Rapids.

William B. Eerdmans Publishing Company.

Nolan, A. 1985. The option for the poor in South Africa, in Vila-Vicencio C, and De Gruchy, J, (eds), Resistance and bope: South African Essays in honour of Beyers Naude, Cape Town. David Phillip, pp. 188-198.

Nolan, A, and Broderick, R. 1987. To nourish the faith: theology of Liberation for South Africa. Hilton. Order of Preachers.

Pratt, J. 1995. A Church of the Poor and for the Poor, in Love of Learning: Desire for Justice,

by Reiser W. (ed). Scramenton. University of Scramenton Press.

Pieterse, H.J.C. 2001. Preaching in a context of Poverty. Pretoria. Unisa

Rawland, C. 1999. Introduction: The Theology of Liberation, in Cambridge companion to Liberation Theology, by Rawland C. (ed). Cambridge. Cambridge University Press, pp. 1-16 Reiser, W. (ed). 1995. Love of Learning: Desire for Justice: Undergraduate education and option for the Poor. Scranton. Scranton University Press

Roux, A. 1999. Every one's guide to the South African Economy. Rivonia. Zebra Saayman, W. 2007. Being Missionary, Being Human: an overview of Dutch Reformed Mission. Pietermaritzburg: Cluster Publications.

Saayman, W. 2008. The sky is red, so we are going to have fine weather: The Kairos Document and the signs of the time. Missionalia 36(1), 16-28

Smith, S. 2005. Ending Global Poverty: A guide to what works. New York. Palgrave. MacMillian.

Sobrino, J. 1991. The crucified Peoples: Yahwehs Suffering Servant today, in The Voices of the Victims: Who will listen to them? London. SCM Press, pp. 120-129

Sunter, C, 1987. The World and South Africa in the 1990's. Tafelberg. Human and Rousseau

West, G. 1999. The Bible and the Poor: A new way of doing theology, in The Cambridge Companion of Liberation Theology, by Rawland C. (ed). Cambridge University Press, pp. 129-152

Whiteford, A. and Mcgrath, M. 1994. Distribution of income inequality in South Africa. Pretoria. H.S.R.C

Wilson, F and Ramphele M, 1989. Uprooting Poverty: The South African Challenge. Cape Town. David Phillip.

Vila-Vicencio, C. 1999. Liberation and the unfinished agenda, in Cambridge Companion to Liberation Theology by Rawland C. (ed). Cambridge. Cambridge University Press, pp. 153-176 Young, J.U. 1990. Black and African Theologians: Siblings or Distant Cousins Maryknoll. N.Y. Orbis Books 